\title{
Immunoelectron Microscopic Study of the Location of Group-Specific and Protein Type-Specific Antigens of Group B Streptococci
}

\author{
By BARBARA WAGNER, ${ }^{1}$ MANFRED WAGNER, ${ }^{1 *}$ \\ VLADIMIR KUBIN² AND MILOŠ RÝ $\mathrm{C}^{3}$ \\ ${ }^{1}$ Research Centre for Molecular Biology and Medicine, Central Institute of \\ Microbiology and Experimental Therapy, Academy of Sciences of the GDR, \\ Beuthenbergstrasse 11, 69 Jena, German Democratic Republic \\ 2Institute of Experimental Medicine, Czechoslovak Academy of Sciences, \\ 10042 Prague, Czechoslovakia \\ ${ }^{3}$ Department of Electron Microscopy, Institute of Hygiene and Epidemiology, \\ 10042 Prague, Czechoslovakia
}

(Received 6 September 1979; revised 6 November 1979)

\begin{abstract}
The ultrastructural location of the group-specific polysaccharide and the type-specific protein antigens $\mathrm{R}$ and $\mathrm{X}$ of group $\mathrm{B}$ streptococci was studied by means of the direct immunoferritin technique. The group-specific antigen was located on the outer wall layer. The specificity of the reaction was proved by the inhibition of labelling after absorption of the antibody-ferritin conjugate with group B polysaccharide. On the other hand, the demonstration of the polysaccharide was not sterically hindered by protein type antigens. As with group A and C streptococci the group polysaccharide could be localized on both the outer and inner surfaces of isolated walls. The protein antigens $\mathrm{R}$ and $\mathrm{X}$ were also demonstrated on the wall surface. The specificity of the reaction was ensured by making use of the enzymic sensitivity of these antigens. The location of the $\mathrm{R}$ protein on long filaments protruding from the cell surface resembles that of $M$ protein of group A streptococci. In contrast to the group polysaccharide both the $\mathrm{R}$ and $\mathrm{X}$ protein antigens are localized only on the outer surface of isolated walls.
\end{abstract}

\section{INTRODUCTION}

Streptococcus agalactiae (group B streptococci) is characterized by a special groupspecific polysaccharide (Lancefield, 1934). It can be further divided into five types according to the presence of four capsular polysaccharide antigens (Lancefield, 1938) and the Ibc protein antigen (Wilkinson \& Eagon, 1971). Until recently, in spite of extensive studies on group- and type-specific antigens using precipitation, immunofluorescence, counterimmunoelectrophoresis and other immunochemical techniques, the exact cytological location of these antigens remained uncertain. However, the finding that type antigens predominate in diagnostic immunofluorescence studies (Moody \& Walker, 1966; Müller, 1967; Kubin et al., 1968; Smith, 1971; Romero \& Wilkinson, 1974) suggests that these antigens are located on the cell surface covering the group antigen.

The precise location of the individual antigens of bacterial walls can be studied by means of immunoelectron microscopic methods, as already demonstrated with a variety of bacteria, including groups A and C streptococci (Swanson et al., 1969; Swanson \& Gotschlich, 
1973; Wagner \& Wagner, 1972a, 1975, 1978; Wagner et al., 1978, 1979b), and the location of type Ia, II and III polysaccharide antigens and the common surface protein Ibc of group B streptococci has also been reported (Kasper \& Baker, 1979).

The aim of the present work was to study the location of the group-specific polysaccharide and the type-specific protein antigens $R$ and $X$ of group $B$ streptococci. The strains with protein type antigens were chosen because these antigens can be removed by proteolytic enzymes without damaging the group-specific polysaccharide. Thus, the specificity of the demonstration of the individual antigens is ensured.

Part of this study, dealing with the group polysaccharide and protein antigen $\mathrm{X}$, was presented at the VIIth International Symposium on Streptococci and Streptococcal Diseases at Oxford (Wagner et al., 1979a). This report gives more detailed results on the location of the group polysaccharide and includes information on the location of the protein type $R$ antigen.

\section{METHODS}

Bacterial strains and growth conditions. The following strains of Streptococcus agalactiae (group B streptococci) from the Czechoslovak National Collection of Type Cultures, Institute of Hygiene and Epidemiology, Prague, were used: strain 24/60 ('Compton'; orig. I. H. Pattison, London), type X; strain 25/60 ('Compton'; orig. I. H. Pattison), type R; strain 58/59 ('090'; orig. R. C. Lancefield, New York), type Ia; strain 8/66 ('090'; orig. R. C. Lancefield), group reference strain without type antigen.

Bacteria were grown with shaking at $37^{\circ} \mathrm{C}$ overnight in Todd-Hewitt broth containing $1 \%(\mathrm{w} / \mathrm{v})$ glucose, harvested by centrifugation and washed with R-K buffer (Ryter \& Kellenberger, 1958). The strains were tested for the Fc factor (Christensen et al., 1976) using a haemagglutination technique (Havliček, 1978). In all strains the reaction was negative.

Preparation of isolated walls. Walls were prepared by disintegrating bacteria as previously described (Wagner et al., 1978), followed by differential centrifugation (Salton, 1964).

Group-specific polysaccharide. Group-specific polysaccharide of group B streptococci was prepared by hot formamide extraction of walls (Fuller, 1938). After dialysis against distilled water the polysaccharide extract was freeze dried.

Group- and type-specific antisera. Strains 8/66 and 24/60 were used for the preparation of antisera to the group polysaccharide and to protein X, respectively. Antisera were elicited in rabbits according to the modified immunization scheme of Jelinkova (1977). A single dose $(0.5 \mathrm{ml})$ was given, and then $7 \mathrm{~d}$ later three doses were administered on three successive days for 4 weeks. Seven days after the last injection the rabbits were bled. The anti-R antiserum, prepared against strain 25/60, was obtained from Dr E. Günther, Central Institute of Microbiology and Experimental Therapy, Jena, G.D.R.

To remove antibodies directed against group-specific polysaccharide, antisera raised against the protein type antigens were absorbed by strain $8 / 66$ cells. Absorption was checked by capillary precipitation (Lancefield, 1934) and counter-immunoelectrophoresis (Kubin et al., 1977).

Ferritin-conjugation of the antisera. Globulin fractions were prepared from the group- and type-specific antisera by adding ammonium sulphate to $40 \%$ saturation and dialysing the suspended sediments against phosphate-buffered saline (PBS), pH 7.2. The IgG fractions were prepared by chromatography on DEAEcellulose (Levy \& Sober, 1960).

The IgG fractions were conjugated with ferritin (five times crystallized; Research Institute for Vaccines, Dessau, G.D.R.) using glutaraldehyde (Wagner \& Wagner, 1972b). The crude conjugates were purified by chromatography on a column $(2.5 \times 100 \mathrm{~cm})$ of Biogel A $1.5 \mathrm{~m}$ (BioRad) which removed non-conjugated IgG and most of the non-conjugated ferritin. PBS was used for elution. After examination by agarose gel electrophoresis the purified fractions were pooled, concentrated against Aquacide I (Calbiochem) and sterilized by filtration (Millipore, $0.45 \mu \mathrm{m}$ pore size).

Treatment with enzymes. Whole organisms and walls were treated with pepsin $(1 \%, \mathrm{w} / \mathrm{v} ;$ Difco $)$ in $0.1 \mathrm{M}$ glycine $/ \mathrm{HCl}$ buffer, $\mathrm{pH} 3 \cdot 0$, for $3 \mathrm{~h}$ at $37^{\circ} \mathrm{C}$ or with trypsin $(1 \%$, w/v; Difco) in R-K buffer, $\mathrm{pH} 7 \cdot 6$, for $3 \mathrm{~h}$ at $22{ }^{\circ} \mathrm{C}$ and were then washed three times in $\mathrm{R}-\mathrm{K}$ buffer.

Electron microscopic technique. For all labelling experiments the direct immunoferritin technique was used. Samples $(0.1 \mathrm{ml})$ of whole organisms and walls were incubated with $0.3 \mathrm{ml}$ of the ferritin-labelled antibody preparations at $37^{\circ} \mathrm{C}$ for $1 \mathrm{~h}$ with shaking. They were then washed three times with R-K buffer, followed by fixation in $2.5 \%(\mathrm{v} / \mathrm{v})$ glutaraldehyde in $0.075 \mathrm{M}$-cacodylate buffer, $\mathrm{pH} 7 \cdot 2$, containing $0.17 \mathrm{M}-$ sucrose and $0.05 \%(\mathrm{w} / \mathrm{v}) \mathrm{CaCl}_{2} .2 \mathrm{H}_{2} \mathrm{O}$ for $30 \mathrm{~min}$ at room temperature. After washing five times with the 

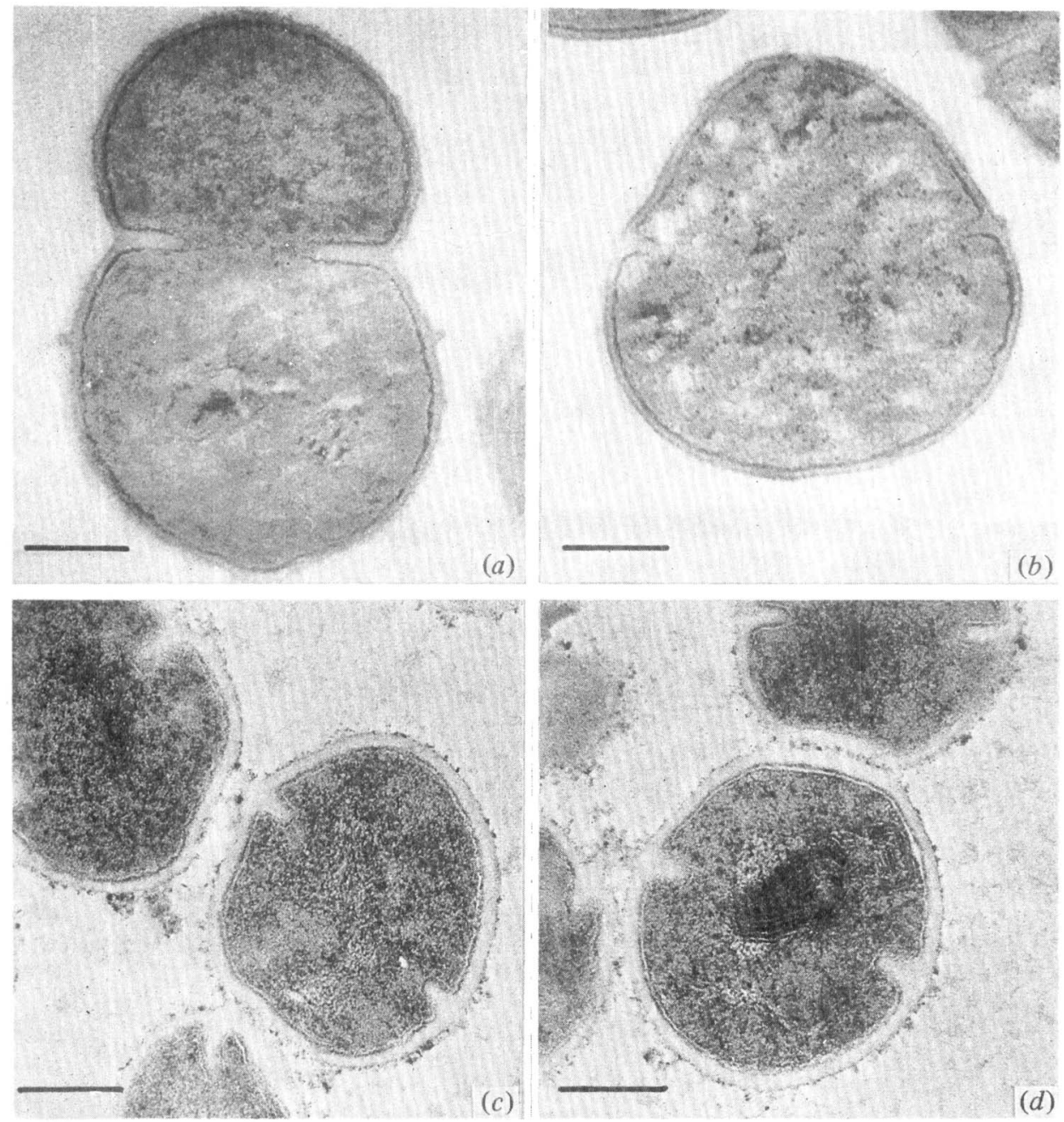

Fig. 1. Morphology of untreated Streptococcus agalactiae. (a) Strain 24/60 (type X); (b) strain 25/60 (type R); (c) strain 24/60, fixed in the culture medium; $(d)$ strain 24/60, fixed after embedding in agar. Bar markers represent $0 \cdot 2 \mu \mathrm{m}$.

same buffer and embedding in $1 \%(\mathrm{w} / \mathrm{v})$ Noble agar, the samples were fixed overnight in $1 \%(\mathrm{w} / \mathrm{v}) \mathrm{OsO}_{4}$ in $\mathrm{R}-\mathrm{K}$ buffer at $4{ }^{\circ} \mathrm{C}$. They were dehydrated in acetone and counterstained with uranyl acetate and phosphotungstic acid (Wohlfarth-Bottermann, 1957), before being embedded in Epon. Ultrathin sections were examined without post-staining. Cells and walls pretreated with proteolytic enzymes were processed in the same way.

The electron microscopes used for examining ultrathin sections were a KEM (VEB Werk für Fernsehelektronik, Berlin, G.D.R.), operating at an accelerating voltage of $60 \mathrm{kV}$, and an Elmiskop I(Siemens), operating at an accelerating voltage of $80 \mathrm{kV}$.

Absorption experiments. Portions of the ferritin-antibody conjugates were further absorbed with $2.5 \%$ $(\mathrm{w} / \mathrm{v})$ rhamnose or $1 \%(\mathrm{w} / \mathrm{v})$ group B polysaccharide (strain B 1723$)$ or with cells of strain $8 / 66(0 \cdot 1 \mathrm{ml}$ cell pellet mixed with $0.5 \mathrm{ml}$ conjugate). The absorptions were carried out at $37^{\circ} \mathrm{C}$ for $1 \mathrm{~h}$ followed by overnight incubation at $4{ }^{\circ} \mathrm{C}$ before the precipitate was removed by centrifuging. 

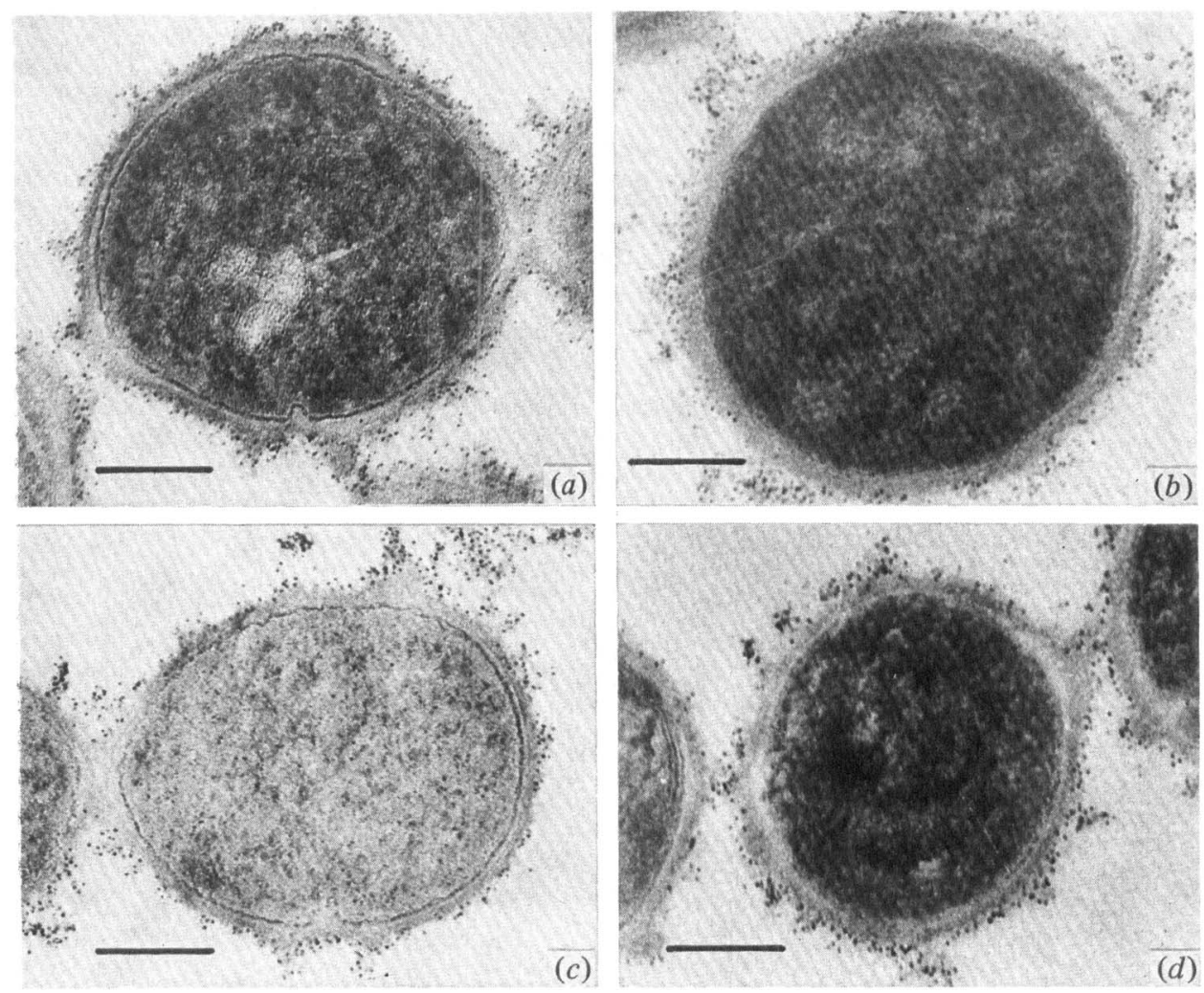

Fig. 2. Demonstration of the group polysaccharide on cells of $S$. agalactiae shown by means of ferritin-conjugated IgG from streptococcal group B-specific antiserum. (a) Strain 24/60 (type X); (b) strain 25/60 (type R); (c) strain 24/60, pretreated with trypsin; (d) strain 24/60, pretreated with pepsin. Bar markers represent $0 \cdot 2 \mu \mathrm{m}$.

\section{RESULTS AND DISCUSSION}

\section{Morphology of the walls}

Untreated cells of $S$. agalactiae exhibited a triple-layered wall structure (Fig. $1 a, b$ ). The surface of the wall was either quite smooth or covered only by very short filaments, which were quite difficult to see. There was no difference in appearance between cocci which had been fixed directly in the culture medium and those embedded in agar prior to fixation (Fig. 1c,d). The ultrastructure of the isolated walls corresponded with the wall profile of the whole cells.

\section{Location of the group-specific polysaccharide}

Cells of all four strains incubated with ferritin-conjugated antibody directed against the group polysaccharide were strongly labelled on their surfaces (Fig. $2 a, b$ ). Most of the ferritin particles appeared to be located directly on the wall and not on filaments. This location was not affected by pretreatment of the cells of strains 24/60 (type X) and 25/60 (type R) with trypsin or pepsin (Fig. $2 c, d$ ), an observation which does not support the hypothesis that the group polysaccharide is masked by the protein type antigens. Contrary to our findings, Kasper et al. (1978) using ferritin-conjugated group B antiserum failed to demonstrate the group polysaccharide on the surface of a type III strain. As already mentioned, in immunofluorescent investigations it has also been observed that predominantly type antigens are involved in the reaction. The discrepancy might be due to differences in cultivation and preparation of the bacteria used for labelling. 

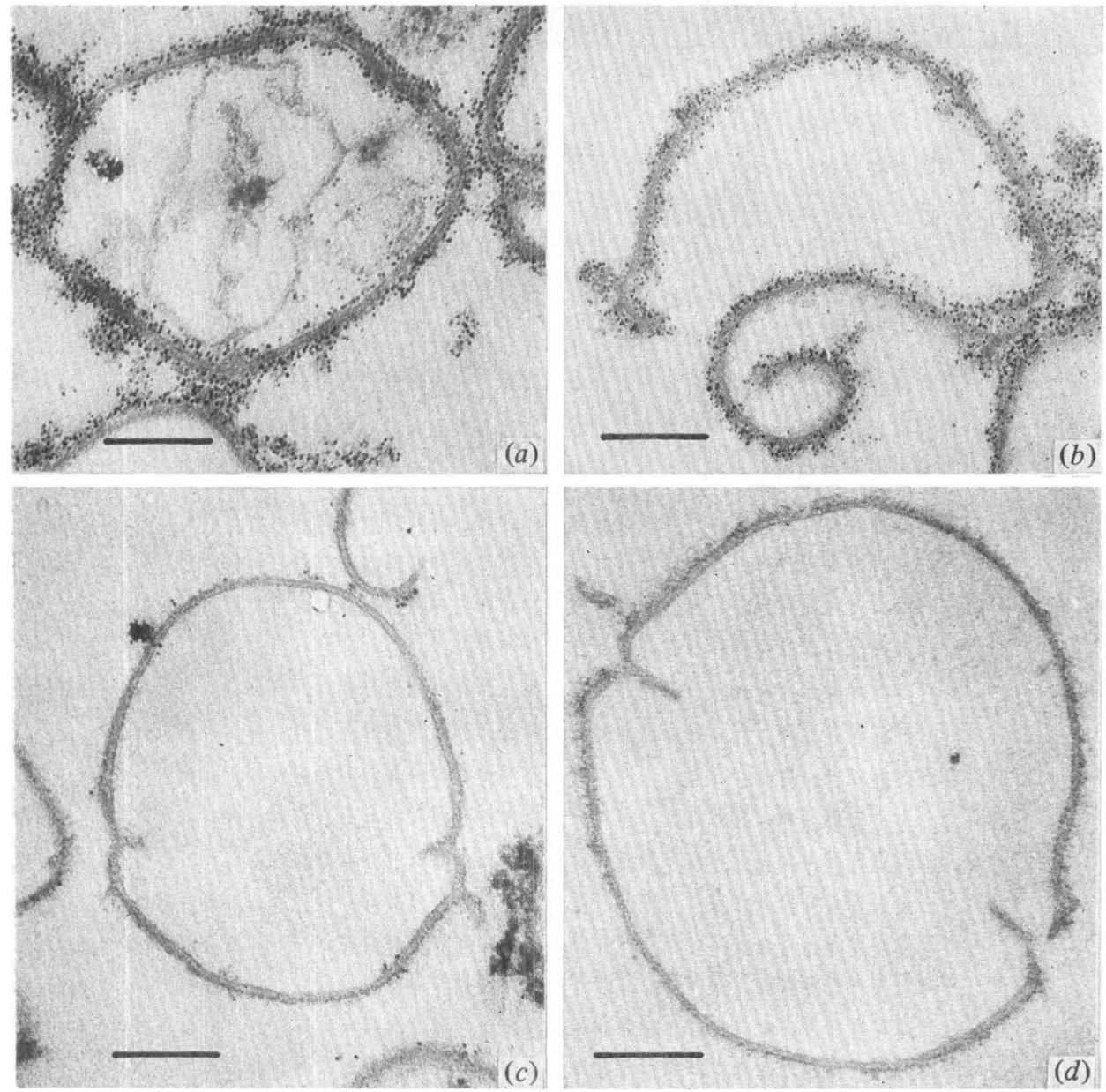

Fig. 3. Demonstration of the group polysaccharide on walls of $S$. agalactiae by means of ferritinconjugated IgG from streptococcal group B-specific antiserum. (a) Strain 24/60 (type X); (b) strain $25 / 60$ (type R); (c) strain 24/60, conjugate previously absorbed with group B polysaccharide; $(d)$ strain $25 / 60$, conjugate previously absorbed with group B polysaccharide. Bar markers represent $0.2 \mu \mathrm{m}$.

Isolated walls of strains $24 / 60$ and $25 / 60$ were strongly labelled on both surfaces (Fig. $3 a$, $b$ ). The majority of the ferritin particles lay at an equal distance from both wall surfaces (Fig. $3 a$ ). As for whole cells, the specificity of the labelling was proved by the complete inhibition of the reaction after previous absorption of the conjugate with group B polysaccharide (Fig. $3 c, d$ ), whereas absorption with rhamnose only resulted in a diminished binding of the conjugate. The possible influence of the Fc-binding factor (Christensen et al., 1976) on the labelling reaction could also be excluded.

The demonstration of the group B polysaccharide on both surfaces of isolated walls is consistent with results obtained for the polysaccharide of group $\mathbf{C}$ streptococci (Wagner \& Wagner, 1975); observations on group A streptococci polysaccharide (Swanson \& Gotschlich, 1973) can be interpreted in the same manner. Thus, the group-specific polysaccharides of these three groups may have the same arrangement, and probably they traverse the whole cell wall. These findings provide further evidence that the streptococcal wall cannot be composed of concentric layers as previously supposed at least for group A streptococci 

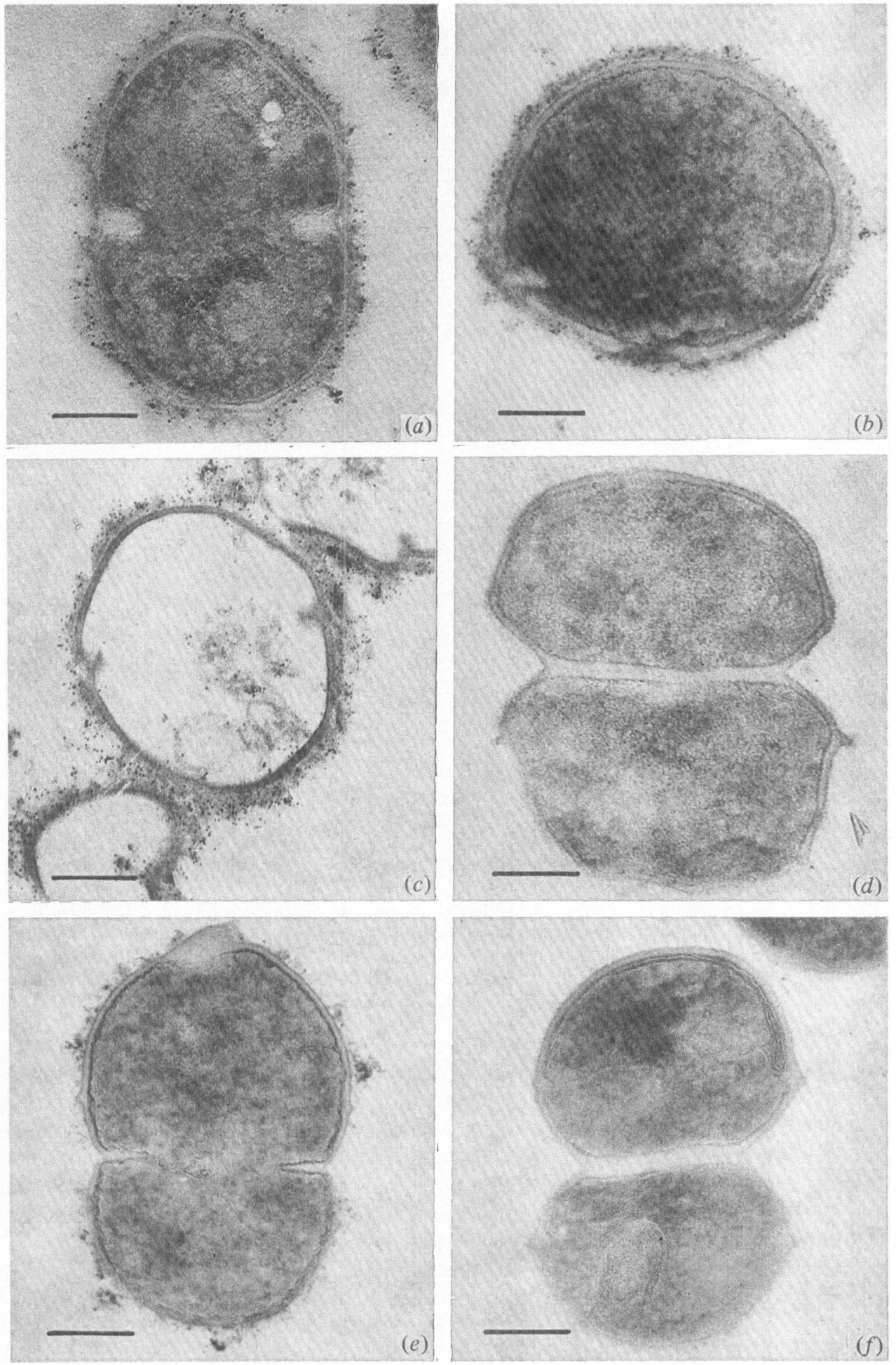

Fig. 4. Demonstration of the protein type antigen $\mathrm{X}$ on cells and walls of $S$. agalactiae by means of ferritin-conjugated IgG from anti-X antiserum. (a) Strain 24/60 (type X); (b) strain 25/60 (type R); (c) walls of strain $24 / 60 ;(d)$ strain $8 / 66$ (without type antigen); $(e)$ strain $24 / 60$, pretreated with trypsin; $(f)$ strain $24 / 60$, pretreated with pepsin. Bar markers represent $0.2 \mu \mathrm{m}$. 
(Krause, 1963; Goldstein, 1972; Heymer et al., 1973). Recently, Kasper \& Baker (1979) have described the demonstration of the type polysaccharides of group B streptococci. However they studied only whole cells and so no statement could be made as to whether these antigens were also located on the inner side of the wall.

\section{Location of the protein type antigen $X$}

Cells of strain 24/60 (type X) incubated with ferritin-conjugated antibody directed against antigen X were strongly labelled (Fig. $4 a$ ) and cells of strain 25/60 (type R) also exhibited a distinct labelling pattern (Fig. $4 b$ ). The reaction of the heterologous strain can be explained by the presence of a small part of $\mathrm{X}$ antigen in $\mathrm{R}$ strains (Pattison et al., 1955). On the other hand, cells of strains 58/59 (type Ia) and 8/66 (without type antigen) did not show any ferritin deposits (Fig. $4 d$ ).

After pretreatment with trypsin (Fig. $4 e$ ) or pepsin (Fig. $4 f$ ) the labelling on the cells of strain 24/60 was diminished or completely abolished. Similar results were obtained for pepsin- or trypsin-pretreated cells of strain 25/60 (type R).

Contrary to the group polysaccharide on isolated walls of strain $24 / 60$, the protein antigen $X$ was localized exclusively on the outer surface (Fig. $4 c$ ).

\section{Location of the protein type antigen $R$}

Cells of strain 25/60 (type R) incubated with ferritin-conjugated antibody directed against antigen $\mathrm{R}$ had large ferritin deposits over the whole surface (Fig. $5 a$ ). The ferritin granules were associated with both the outermost layer of the wall and with long filamentous protrusions from the surface. This location closely resembles that of $\mathrm{M}$ protein of group A streptococci (Swanson et al., 1969; Wagner \& Wagner, 1972a) and is also in agreement with earlier immunofluorescent investigations (Köhler \& Wagner, 1962). A close biochemical similarity between the $M$ and $R$ proteins has also been described (Johnson, 1975; Johnson \& Beachey, 1979). On untreated cells of strain $25 / 60$ only short filaments were visible; these may have been made more obvious by the antigen-antibody reaction (Lai et al., 1973; Emyanitoff et al., 1976). Isolated R28 protein was reported to be trypsin-resistant (Johnson, 1975) although in our experiments labelling of the $\mathbf{R}$ antigen could be inhibited by treating walls with trypsin or pepsin.

Isolated walls of strain $25 / 60$ were predominantly labelled on their outer surface, although the inner surface was also labelled with some diffusely distributed ferritin granules. This labelling of the inner side of the wall could not be removed by absorption of the conjugate with rhamnose (Fig. 5 c). Absorption of the conjugate with group B polysaccharide or with cells of strain $8 / 66$ did not alter the labelling intensity on the outer wall surface, whereas the labelling on the inner wall surface was completely inhibited (Fig. $5 b$ ). Therefore, all further experiments were made with conjugate absorbed with group B polysaccharide.

Walls pretreated with trypsin exhibited a smooth outer surface without filamentous protrusions (Fig. $5 e$ ) and there was no labelling by the conjugate. After limited digestion by pepsin (Beachey et al., 1974) the walls were not labelled although short filaments were still present on the outer surface (Fig. $5 d$ ).

Using anti-R conjugate, absorbed only once with strain $8 / 66$ cells, walls of strain $24 / 60$ (type X) were slightly labelled on both surfaces (Fig. $6 a$ ). After additional absorption of the conjugate with group B polysaccharide labelling was almost completely abolished (Fig. 6b).

These results show that, similar to the $\mathrm{X}$ antigen, the $\mathrm{R}$ protein is located only on the outer surface of the wall. The T and $\mathrm{M}$ proteins (Wagner et al., 1979b; B. Wagner \& $\mathrm{M}$. Wagner, unpublished observations) have also been found to have the same asymmetric arrangement.

Location on the outer surface may be a common feature of all streptococcal wall pro- 

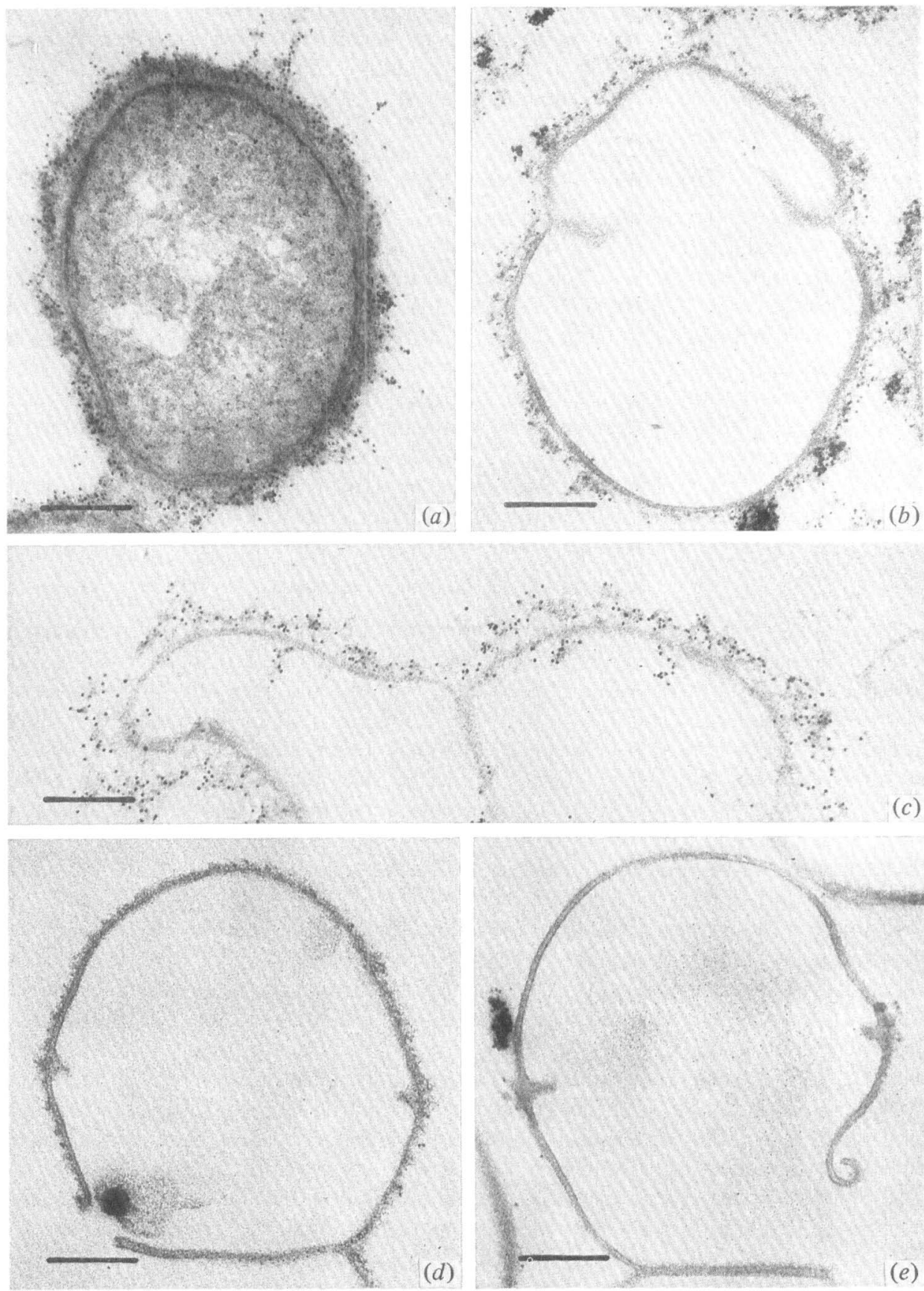

(c)

Fig. 5. Demonstration of the protein type antigen R on cells and walls of $S$. agalactiae strain $25 / 60$ (type R) by means of ferritin-conjugated IgG from anti-R antiserum. (a) Labelling with the unabsorbed conjugate; (b) conjugate previously absorbed with group B polysaccharide; (c) conjugate previously absorbed with rhamnose; $(d)$ labelling after limited digestion with pepsin; $(e)$ labelling after treatment with trypsin. Bar markers represent $0 \cdot 2 \mu \mathrm{m}$. 


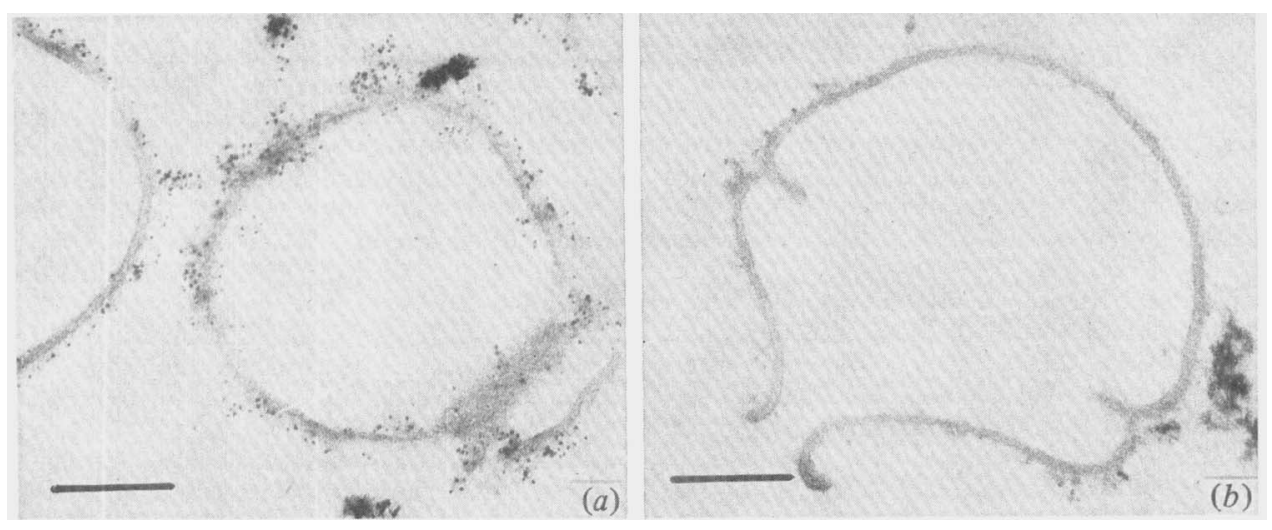

Fig. 6. Reaction of walls of S. agalactiae strain 24/60 (type X) with ferritin-conjugated IgG from anti$\mathrm{R}$ antiserum. (a) Labelling with the unabsorbed conjugate; $(b)$ conjugate previously absorbed with group B polysaccharide. Bar markers represent $0 \cdot 2 \mu \mathrm{m}$.

teins. However, this fact does not support the hypothesis of a simple layered arrangement of the wall components. We have already shown that both the group polysaccharides of groups $\mathrm{B}$ and $\mathrm{C}$ streptococci and the peptidoglycan of groups A and $\mathrm{C}$ streptococci (Wagner et al., 1978; Rýc et al., 1979) are accessible from the outer as well as from the inner wall surface, results which strongly suggest a mosaic-type structure of the wall.

We thank Dr E. Günther, Jena, for the generous gift of anti-R serum and Dr J. Havliček, Prague, for estimating the occurrence of the Fc-binding factor in the streptococcal strains used. For their excellent technical assistance the authors wish to express thanks to Mrs I. Otum and Miss S. Kunze.

\section{REFERENCES}

Beachey, E. H., Campbell, G. L. \& OfeK, I. (1974). Peptic digestion of streptococcal $M$ protein. II. Extraction of $\mathrm{M}$ antigen from group A streptococci with pepsin. Infection and Immunity 9, 891-896.

Christensen, P., Johannson, B. G. \& Kronwall, G. (1976). Interaction of streptococci with the Fc fragment of IgG. Acta pathologica et microbiologica scandinavica B84, 73-76.

Emyanitoff, R. G., Rucinsky, T. E. \& Birdsell, D. C. (1976). Electron microscopy of antibodylabelled cells of Streptococcus mutans. Canadian Journal of Microbiology 22, 891-895.

Fuller, A. T. (1938). The formamide method for the extraction of polysaccharide from haemolytic streptococci. British Journal of Experimental Pathology 19, 130-139.

Goldstein, I. (1972). Réactions immunologiques croisées hôte-parasite. Cas particulier du streptocoque du groupe A. Revue d'Immunologie 36, 203-266.

HAVLIČEK, J. (1978). Occurrence of Fc-reacting factor in acid extracts of Streptococcus pyogenes and its relationship to $\mathrm{M}$ protein. Experimental Cell Biology 46, 146-151.

Heymer, B., SchäFer, H. \& Haferkamp, O. (1973). Vergleichende elektronenoptische und biochemische Untersuchungen über die Wirkung einer Streptomyces albus Endo- $N$-acetylmuramidase auf die Streptokokkenzellwand. Medical Microbiology and Immunology 158, 193-208.

Jelinkova, J. (1977). Group B streptococci in the human population. Current Topics in Microbiology 76, 127-165.

JoHnson, R. H. (1975). Characterization of group A streptococcal R-28 antigen purified by hydroxyapatite column chromatography. Infection and Immunity 12, 901-909.

Johnson, R. H. \& Beachey, E. H. (1979). Purification and characterization of group-A streptococcal type-3 $R$ protein: relationship to $M$ protein. In Pathogenic Streptococci: Proceedings of the VIIth International Symposium on Streptococci and Streptococcal Diseases, pp. 40-41. Edited by M. T. Parker. Chertsey, Surrey: Reedbooks Ltd.

Kasper, D. L. \& BAKer, C. J. (1979). Electron microscopic definition of surface antigens of group B Streptococcus. Journal of Infectious Diseases 139, 147-151.

Kasper, D. L., GorofF, D. K. \& Baker, C. J. (1978). Immunochemical characterization of native polysaccharides from group B Streptococcus: the relationship of the type III and group B determinants. Journal of Immunology 121, 1096-1105.

KöHLER, W. \& WAGNER, M. (1962). Die Typisierung hämolysierender Streptokokken der Gruppe A. IV. Das Vorkommen von R28-Antigen bei 
Streptokokken der Gruppen B, C und G und sein Nachweis mit fluoresceinmarkierten Antikörpern. Zeitschrift für Immunitätsforschung, experimentelle und klinische Immunologie 123, 200207.

KRAUSE, R. M. (1963). Symposium on relationship of structure of microorganisms to their immunological properties. IV. Antigenic and biochemical composition of hemolytic streptococcal cell walls. Bacteriological Reviews 27, 369-380.

Kubin, V., Franek, J. \& Prochazka, O. (1968). Use of fluorescent antibodies for the identification of streptococci. II. Determination of Streptococcus agalactiae (group B). Journal of Hygiene, Epidemiology, Microbiology and Immunology 12, 315-323.

Kubin, V., Jelinkova, J. \& Franek, J. (1977). Streptococcus group B typing: comparison of the counter-immunoelectrophoresis with the precipitin method. Zentralblatt für Bakteriologie, Parasitenkunde, Infektionskrankheiten und $\mathrm{Hy}$ giene (Abteilung I) 238, 330-335.

LaI, C. H., Listgarten, M. \& Rosan, B. (1973). Serology of Streptococcus sanguis: localization of antigens with unlabeled antisera. Infection and Immunity 8, 475-481.

LANCEFIELD, R. C. (1934). A serological differentiation of specific types of bovine haemolytic streptococci (group B). Journal of Experimental Medicine 59, 441-458.

LANCEFIELD, R. C. (1938). Two serological types of group B haemolytic streptococci with related, but not identical type-specific substances. Journal of Experimental Medicine 67, 25-39.

LEVy, H. B. \& SobeR, H. A. (1960). A simple chromatographic method for preparation of gammaglobulin. Proceedings of the Society for Experimental Biology and Medicine 103, 250-252.

Moody, M. D. \& WALKer, H. (1966). Fluorescent antibody identification of group B streptococci from human infections. Proceedings of the IXth International Congress of Microbiology, Moscow, 717.

MÜLLER, G. (1967). Der fluoreszenzserologische Nachweis von Streptokokken der Gruppe B. Monatshefte für Veterinärmedizin 22, 64-69.

Pattison, I. H., Matthews, P. R. J. \& Howell, D. G. (1955). The type classification of group B streptococci, with special reference to bovine strains apparently lacking in type polysaccharide. Journal of Pathology and Bacteriology 69, 51-60.

Romero, R. \& Wilkinson, H. W. (1974). Identification of group B streptococci by immunofluorescence staining. Applied Microbiology 28, 199204.

RÝc, M., Wagner, M. \& Wagner, B. (1979). Peptidoglycan localization in the cell wall of group-A and -C streptococci. In Pathogenic Streptococci: Proceedings of the VIIth International Symposium on Streptococci and Streptococcal Diseases, pp. 46-48. Edited by M. T. Parker. Chertsey, Surrey: Reedbooks Ltd.

Ryter, A. \& Kellenberger, E. (1958). Etude au microscope électronique de plasma conténant de l'acide déoxyribonucleic. I. Les nucléoides des bacteries en croissance active. Zeitschrift für Naturforschung 13b, 597-605.

Salton, M. R. J. (1964). The Bacterial Cell Wall, p. 58. Amsterdam: Elsevier.

SMITH, T. B. (1971). Clinical application of immunofluorescence. III. Identification of Lancefield group B streptococci. Infection and Immunity 4, 189-193. Swanson, J. \& Gotschlich, E. C. (1973). Electron microscopic studies of streptococci. II. Group A carbohydrate. Journal of Experimental Medicine 138, 245-258.

Swanson, J., Hsu, K. C. \& Gotschlich, E. C. (1969). Electron microscopic studies on streptococci. I. $\mathrm{M}$ antigen. Journal of Experimental Medicine 130, 1063-1091.

WAGNER, B. \& WAGNER, M. (1972a). Immunelektronenmikroskopischer Nachweis von Zellwandantigenen bei Streptokokken. I. Vergleichende Darstellung des M-Proteins von Streptococcus pyogenes mit ferritin-, peroxydase- und ferrocenmarkierten Antikörpern. Zentralblatt für Bakteriologie, Parasitenkunde, Infektionskrankheiten und Hygiene (Abteilung I) 222, 468-483.

WAGNER, M. \& WAGNER, B. (1972 b). Glutaraldehyd als Kupplungsagens für die Herstellung ferritinmarkierter Antikörper. Zentralblatt für Bakteriologie, Parasitenkunde, Infektionskrankheiten und Hygiene (Abteilung I) 221, 100-105.

WAGNER, B. \& WAGNER, M. (1975). Immunelektronenmikroskopischer Nachweis von Zellwandantigenen bei Streptokokken. II. Der Nachweis des gruppenspezifischen Polysaccharids von Streptokokken der Gruppe C mit ferritin- und peroxydasemarkiertem Helix pomatia-Agglutinin. Zentralblatt für Bakteriologie, Parasitenkunde, Infektionskrankheiten und Hygiene (Abteilung I) 231, 81-91.

WAGNER, M. \& WAGNER, B. (1978). Die Verwendung von Lysozym-Peroxydase-Konjugaten zum elektronenmikroskopischen Nachweis von Peptidoglykan in der Zellwand von Streptokokken. Zentralblatt für Bakteriologie, Parasitenkunde, Infektionskrankheiten und Hygiene (Abteilung I) 240, 302-312.

WAGNeR, M., WAGNER, B. \& RÝC, M. (1978). An electron microscopic study of the location of peptidoglycan in group $\mathrm{A}$ and $\mathrm{C}$ streptococcal cell walls. Journal of General Microbiology 108, 283-294.

WAGner, M., Kubin, V., WAGner, B. \& RÝc, M. $(1979 a)$. Immunoelectron microscopic demonstration of the group-specific and protein typespecific antigens of group B streptococci. In Pathogenic Streptococci: Proceedings of the VIIth International Symposium on Streptococci and Streptococcal Diseases, pp. 147-148. Edited by M. T. Parker. Chertsey, Surrey: Reedbooks Ltd.

WAGNER, B., SCHMIDT, K.-H. \& WAGNER, M. (1979 b). Immunoelectron microscopic localization of $\mathrm{T}$ proteins in the cell wall of Streptococcus pyogenes. Zentralblatt für Bakteriologie, Parasitenkunde, Infektionskrankheiten und Hygiene (Abteilung I) 244, 192-201. 
Wilkinson, H. W. \& Eagon, R. G. (1971). Typespecific antigens of group B type Ic streptococci. Infection and Immunity 4, 596-604.

WoHLfarth-BotTermann, K. E. (1957). Die Kon- trastierung tierischer Zellen und Gewebe im Rahmen ihrer elektronenmikroskopischen Untersuchung an ultradünnen Schnitten. Naturwissenschaften 44, 287-288. 